\title{
INNOVATION STRATEGIES OF ENERGY FIRMS
}

\author{
Costa-Campi, M.T. ${ }^{1}$, Duch-Brown, N. ${ }^{2}$, García-Quevedo, J. ${ }^{3}$ \\ ${ }^{1}$ Department of Economics, Chair of Energy Sustainability and Barcelona Institute of \\ Economics (IEB), University of Barcelona; Barcelona, Spain. E-mail: mtcosta@ub.edu \\ 2 Institute for Prospective Technological Studies, European Commission; Chair of \\ Energy Sustainability and Barcelona Institute of Economics (IEB), University of \\ Barcelona, Spain. E-mail: E-mail: nestor.duch-brown@ec.europa.eu \\ ${ }^{3}$ Department of Economics, Chair of Energy Sustainability and Barcelona Institute of \\ Economics (IEB), University of Barcelona, Barcelona, Spain. Av/Diagonal 690. 08034 \\ Barcelona, Spain. E-mail: jgarciaq@ub.edu (corresponding author)
}

\begin{abstract}
Investment by energy firms in innovation can have substantial economic and environmental impacts and benefits. Firms engage in innovation for different reasons. The main objective of this paper is to analyse the role that the different innovation objectives have on firms' decisions to invest in each of three types of innovation activity: namely internal $R \& D$, external $R \& D$ and the acquisition of advanced machinery, equipment or software. We consider four objectives: process innovation, product innovation, reducing environmental impact and meeting regulatory requirements. With this approach, we examine how energy firms innovate to reduce their environmental impact in comparison with other innovation objectives. In carrying out the empirical analysis, we draw on data for private energy firms included in the Spanish Technological Innovation Panel (PITEC) for the period 2004-2016. In the empirical analysis we take the potential persistence of innovation activities into account and we use multivariate probit models to control for possible complementarities between the different R\&D and innovation investments. Our results show that internal and external R\&D are undertaken to address environmental objectives and to meet regulatory requirements while the acquisition of advanced machinery has the purpose of developing process innovations.
\end{abstract}

KEYWORDS: energy, R\&D, innovation, environment, regulation, complementarity

Acknowledgments: We are very grateful for the suggestions and comments from two anonymous referees that were very useful for improving the paper. We are also grateful to Xavier Massa for his excellent research assistance and to Elisenda Jové for very valuable comments. Previous versions of this paper were presented at the Energy Economics Iberian Conference (Lisbon, Portugal, February 2016); at the SPRU Wednesday Seminars (University of Sussex, UK, May 2016), at the XIX Applied Economics Meeting (Seville, Spain, June 2016); and at the $39^{\text {th }}$ International Association for Energy Economics Conference (Bergen, Norway, June 2016). We would like to thank the participants at these meetings for their helpful comments. We acknowledge financial support from the Chair of Energy Sustainability (IEB, University of Barcelona) and from the Ministry of Economy and Competitiveness (Project ECO2015-69107-R, MINECO/FEDER, EU). 


\section{INTRODUCTION}

The energy sector is experiencing a major transformation and although innovation did not until recently occupy a central position in this industry, today it is one of the main driving forces behind these transformative changes (Eurelectric, 2013; Bointner, 2014). Indeed, sustainable innovation would appear to be critical if energy firms hope to successfully tackle the challenges posed by increasing competitiveness, energy efficiency and climate change mitigation (Anadon et al., 2011; OECD, 2011).

Firms engage in innovation for different reasons and understanding these reasons may help explain their R\&D strategies and behaviour and the type of innovation they seek to achieve (OECD, 2005). Establishing innovation objectives is the starting point of the innovation process (Jakobsen and Clausen, 2016). Indeed, the role played by firms' objectives is receiving increasing attention in empirical research on innovation at the firm level (Costa-Campi et al., 2015b; Jakobsen and Clausen, 2016; Jove-Llopis and SegarraBlasco, 2016; Leiponen and Helfat, 2010).

The main research question of this paper is to understand the effects of the various innovation objectives - process innovation, product innovation, reducing environmental impact and meeting regulatory requirements - on the decision of energy firms to invest in either internal $R \& D$, external $R \& D$ or advanced machinery to achieve them. Internal $\mathrm{R} \& \mathrm{D}$ is the main input when increasing the stock of knowledge and when innovating, but innovation has many sources other than internal R\&D. Firms can also purchase external $R \& D$ or even acquire machinery in order to innovate and improve their technology level and to meet competitiveness and environmental concerns. The choice of R\&D strategy has received considerable attention in the economics of innovation literature, especially as regards the decision as to whether to 'make or buy R\&D' (Narula, 2001; Veugelers and Cassiman, 1999). However, to the best of our knowledge, few studies (an exception being Cohen and Sanyal, 2008) have examined the R\&D choices of energy firms.

Similarly to Jakobsen and Clausen (2016), we consider that innovation attempts to fulfil a specific objective and this influences the innovation process. The objectives differ by type of innovation and meeting these objectives may equally require different innovation strategies. Some may require investment in $R \& D$ and others may be achieved by purchasing new machinery or equipment. Traditionally, in the energy industry, the implementation of new, or significantly improved, production processes has been the main motive for innovating, with the objective thereby of increasing capacity and improving efficiency. Such innovations are frequently achieved by acquiring new machinery that incorporates new technological advances.

Although these continue to be salient motives underpinning innovation, the energy industry has undergone a significant transformation and other factors have emerged as drivers of innovation. Firms today innovate to reduce their environmental impact as well as in response to regulatory pressures closely tied to climate change targets. Successful innovation may require increasing the stock of knowledge with $R \& D$ investment, accessing new skills and services through external R\&D or acquiring new machinery as has been discussed in the previous section. The achievement of environmental objectives may require changes in knowledge search strategies and the accessing of new skills through external R\&D and collaboration with other firms and stakeholders. 
To answer our research question we have carried out an empirical analysis for energy firms. We consider the firms classified as electricity, gas, steam and air conditioning supply (NACE 35) and we include all activities related with the generation, transformation, distribution and retailing of energy. Empirical analyses of the R\&D and innovative behaviour of energy firms are frequently constrained by a lack of data (Anadon et al., 2011; GEA, 2012; Gallagher et al., 2012). In this paper, we rely on information drawn from the Spanish Technological Innovation Panel (PITEC) for the period 20042016 to carry out our econometric estimations. The data collected for this panel is based on information taken from the Community Innovation Survey conducted in Spain, adhering to the guidelines of the Oslo Manual of the OECD (OECD, 2005).

For the empirical analysis we use multivariate models that are well suited to the analysis of the decisions of economic agents. Consequently, and following recent literature (Cassiman and Veugelers, 2006; Cruz-Cázares, 2013; Catozzella and Vivarelli, 2014), with these models we take into account potential complementarities between innovation activities. We examine whether the decisions are taken independently or, on the contrary, whether firms combine different procedures in their innovation strategies. In this empirical analysis, we take the potential persistence of innovation activities into account and examine whether differences occur with respect to the three innovation choices under study.

After this introduction, the rest of this paper is organised as follows. In the next section, we provide a brief discussion of what it is that motivates energy firms to innovate in the current liberalised situation. In this discussion, we consider the ways firms opt to innovate and we discuss different business models. The third section presents the database, the descriptive statistics, the model specification and the empirical methodology. The fourth section presents the results of the econometric estimations, including extensions and robustness checks. The last section concludes.

\section{INNOVATION STRATEGIES OF ENERGY FIRMS}

The transformation of the energy industry to deal with climate change is occurring along the value chain both upstream and downstream. Although technology is a critical enabler for transforming the energy system, innovations in business models, in processes and in market design are also necessary (IRENA, 2018). Recent studies on energy firm's business models question the compatibility of current models and emphasize that existing business models should be refreshed to reflect the new challenges emerging in the energy sector such as climate change, the increasing share of renewable energies, digitalization, demand side management and consumer empowerment (Boons and Lüdeke-Freund 2013; Klose et al., 2010; Richter, 2013).

Disruptive technological changes are shaping a totally different model from that of a conventional energy supply. The emergence of renewable energy is displacing conventional generation and impacting the transmission and distribution system and its operation. In turn, the incorporation of information technology allows more complete information to be given to consumers, who can now take a more active role on the demand side, which should change how the system works. Networks are no longer simply physical channels of electricity flows but operate in accordance with the information users make available about their consumption patterns. Smart grids and smart meters radically 
transform the energy model. Moreover, this digital technological development facilitates a new role for the consumers (Rayna and Striukova, 2016; Perez-Arriaga et al., 2017). This technological change involves, together with the traditional energy supply, new complementary services and new contracts to minimize consumer price volatility in a context of real time pricing (Bointner, 2014; GEA, 2012).

All these changes require the adoption of a business innovation approach and the investment of private companies in $\mathrm{R} \& \mathrm{D}$, given that public funds have proven to be insufficient on their own (Wiesenthal et al., 2012). Ultimately, the literature emphasizes the fact that innovation is the only way the industry can face the changes that are taking place (Richter, 2013). The data offer evidence in support of this trend. After nearly two decades of falling R\&D investment in the energy sector, we are witnessing a recovery (Jamasb and Pollitt, 2015; Bointner, 2014; Wiesenthal et al., 2012). The new trend reflects the innovation strategies being adopted by companies in the sector, a trend that is dominated by externally performed $\mathrm{R} \& \mathrm{D}$, in contrast to the situation in other sectors.

From an evolutionary economics framework, firms differ in their innovation approaches and objectives (Jakobsen and Clausen, 2016; Nelson and Winter, 1982). One of the main challenges that firms face is in deciding which innovation strategy to develop and how to acquire the necessary technology to accomplish their innovation goals. Until recently, the most important reason for energy firms to innovate was oriented towards process innovation to increase production capacity aimed at strengthening their competitive advantage in line with the energy market's coordinates and security of supply (Anadon et al., 2011). Recently, the penetration of renewable energies as well as the empowerment of consumers -which the digitalisation allows- within the new electrical system has created the need to develop an increasingly flexible system to guarantee security of supply and meet new energy and environmental goals (IRENA, 2018). Another important objective regarding process innovation among energy firms is improving power system flexibility for the energy transition through the purchase of new equipment and incorporating information and communication technologies within networks and meters. Since the transformation towards a climate neutral economy is becoming a higher priority for policy makers, it is not surprising that energy firms are now defining their innovation objectives in terms of reducing environmental impacts or meeting regulatory requirements (Costa-Campi et al., 2017).

In short, energy firms seek to increase their portfolio both in the upstream and downstream markets. Their objectives also include reducing costs in the medium term (especially in CAPEX), increasing innovation in operation and maintenance (OPEX), increasing energy efficiency, complying with new environmental regulations and meeting global commitments, innovating in the network management of power evacuation and, finally, furthering decentralization. These processes of constant innovation mean the sector's industrial processes are yielding to a disruptive technological transformation. In turn, firms are now having to work bottom up, rather than top down, as they have been to date (Daim et al., 2013).

In the new context, where the importance of an environmental agenda for industry has been on the rise at an international level, what is clear from the business model innovation literature is the need for energy businesses to create, deliver and give value to the customers (Osterwalder and Pigneur, 2009; Teece, 2010). To accomplish the different innovation goals mentioned above (product innovation, process innovation, reducing 
environmental impacts and meeting regulatory requirements) energy firms can improve their business model innovation through organizational structure (internal R\&D strategy and acquisition of machinery strategy) and external partnerships (external R\&D strategy) to foster the accumulation of know-how and innovation capabilities (Richter, 2013). Doing R\&D in-house and developing their own technology is one well-known strategy in the innovation literature. However, due to the existence of high uncertainty in the energy sector (Sanyal and Cohen, 2008), combined with such aspects as capital-intensive innovation requirements, the long life of existing installations, the amount of time required for new technologies to mature and become competitive in the market, may have caused a slowdown in the internal R\&D ratios among energy firms (Gallagher et al., 2012).

In contrast, an alternative strategy is to acquire technology externally. According to the energy sector's own reports (Eurelectric, 2013) and the literature (Daim et al., 2013), energy firms have oriented their innovation strategy towards close cooperation with other companies, given the high costs and the diversity of activities and knowledge (both hard and soft) needed. To tackle this situation, companies have adopted a risk-sharing strategy, conducting $\mathrm{R} \& \mathrm{D}$ externally, which enables them to undertake various projects with the same amount of resources but using collaborative $R \& D$ as a hedge against uncertainty (Cohen and Sanyal, 2008).

From a resource-based view approach, firms resort to external $R \& D$ when they need to develop specific technologies for which they do not have the appropriate internal resources (Cruz-Cázares et al., 2013). In a context of energy transition towards a low carbon economy, where environmental innovations face a complex task due to high levels of uncertainty and novelty, it is essential new knowledge that is outside core competences through external R\&D (Jakobsen and Clausen, 2016). Likewise, the literature examining environmental innovations concludes that here too they are more likely to be developed in cooperation (Horbach, 2008; De Marchi, 2012).

Finally another strategy frequently employed by energy firms to innovate is that of the acquisition of new machinery. The incorporation of new equipment is the main way to update the technology used. This strategy means that the company relies on its external suppliers when introducing innovations (Bönte and Dienes, 2013). Most new energy technology has been developed by large electrical equipment manufacturers (Sanyal and Cohen, 2009). The main drawbacks here are that such acquisitions may not improve the firm's ability to absorb knowledge and that this embodied technological change is also available to a firm's competitors

\section{DATA}

\subsection{Database and descriptive statistics}

Our dataset is a sub-sample of the Technological Innovation Panel (PITEC) for Spanish firms. PITEC includes exhaustive information on the characteristics and innovative activities of more than 12,000 Spanish firms for the period 2003-2016. PITEC is the result of cooperation between the Spanish National Statistics Institute and the COTEC foundation and seeks to make data available from the Community Innovation Survey (CIS), conducted annually following the guidelines of the OECD's Oslo Manual. While 
the EU-wide CIS database offers information on cross-section observations, the Spanish PITEC is able to identify firms in several waves and, thus, provides a large panel of innovative firms. From the full sample of firms, we select those that correspond to the energy industry as defined below.

Our operational definition of the energy sector includes all activities related with the generation, transformation, distribution and retailing of energy. We do not include the oil industry (NACE 19) where the number of firms in PITEC is very low, with no more than two or three annual observations and because their innovation strategies are substantially different from other energy firms. In PITEC, the data for the two divisions of the NACE Rev. 2 classification, Electricity, gas, steam and air conditioning supply (NACE 35) and Water collection, treatment and supply (NACE 36), are aggregated. To separate water companies from energy companies, we rely on the fact that in Spain, following the energy liberalisation process of the late nineties, all gas and electricity companies are privately owned whereas almost all water companies are state-owned. Therefore, to ensure we focus on energy firms, we remove all the state-owned firms from the sample of utilities included in PITEC. Industries in the NACE 35 include firms involved in a variety of activities (electric power generation, transmission and distribution, manufacture of gas, distribution of gaseous fuels, and steam and air conditioning supply) that may differ in their innovation strategies and business models. Unfortunately, PITEC does not provide any additional disaggregation and we are unable to identify firms any further than this.

To analyse the decisions to invest in R\&D and innovation by energy firms, we control for the fact that some firms may simply not be willing to innovate. We follow the recent literature (Savignac, 2008; D'Este et al., 2012; Blanchard et al., 2013, Pellegrino and Savona, 2017) and focus exclusively on potential innovators. To do so, we exclude from the sample firms that satisfy the following three conditions: they have never innovated; they do not perceive any obstacle to innovation; and they declare they have no need to innovate. The number of firms that we have excluded on this basis is only nine.

Although PITEC provides information for 2003, the data for that year are incomplete. However, as we use the lags of independent variables for some items in the estimations, we also use the data for 2003 to avoid the loss of information before removing all the observations corresponding to that particular year. After applying these filters, 653 observations are available for 95 energy companies forming an unbalanced panel for the period 2004-2016 of which 15 are present during the whole period of analysis. The size and composition of the panel are reasonable, and comparable to others used in the literature (see, for instance, Costa-Campi et al. 2014). Regarding the composition of the sample, $85 \%$ of the observations come from firms that are present in the data for at least 6 years. These firms amount to $55 \%$ of the firms included in the sample. 18 firms appear only once (one year), i.e., $3 \%$ of total observations.

Spain's electricity and gas regulations are fully harmonised with European standards and the country's energy industry has undergone a similar process of liberalisation and transformation to that experienced in other European countries. This process has meant an increase in the number of firms and a corresponding reduction in market concentration. A comparison of Spanish firms with their European counterparts reveals that the former are close to the average in terms of their structural business indicators, including turnover and gross added value per employee, the proportion of personnel costs in production costs and investment rates (Costa-Campi et al., 2014). 
Table 1 shows the main characteristics of Spain's innovative energy firms as included in the PITEC database. The table shows that they are big, with an average of 619 employees, although the median lies around 296. Similarly, the average firm has been operating for 35 years; however, the dataset includes firms with more than 100 years' experience as well as recently created start-ups. Other characteristics include an indicator as to whether a firm forms part of a larger group or not, if it has foreign capital participation in its ownership structure, and if it has received public subsidies for R\&D activities.

This table also shows the descriptive statistics of our variables of interest, including firms that i) invest in internal $R \& D$; ii) invest in external $R \& D$; and, iii) invest in the acquisition of machinery, equipment and software. As defined by the Frascati Manual, internal R\&D comprises all the R\&D performed within the enterprise in order to increase the stock of knowledge and to devise new applications. External R\&D comprises the acquisition of $R \& D$ services from private or public organisations. Although R\&D is an important input in the innovation process, it should be taken into account that it is only an input and does not provide a measure of the impact of R\&D investment (Mairesse and Mohnen, 2010). Finally, in the category of advanced machinery, we include, in line with the Oslo Manual's (OECD, 2005) definition, the acquisition of advanced machinery, equipment, computer hardware and software, and land and buildings that are required to implement product or process innovation. This category does not, however, include the capital expenditures that are part of $R \& D$.

In the period under consideration, on average, more than half the energy companies (52\%) reported performing internal R\&D activities, $41 \%$ subcontracted $R \& D$ activities and $22 \%$ reported acquiring advanced machinery, equipment or software. In addition, we have included information on disembodied technological change, defined as the purchase or licensing of patents and non-patented inventions, know-how, and other types of knowledge from other enterprises or organisations (OECD, 2005). Only a few firms (6\%) report performing this innovation activity and therefore we will not consider it in detail in our analysis.

\section{Table 1}

Energy firms appear to adopt the innovation strategies at their disposal depending on their specific innovation objectives. PITEC allows us to undertake a comprehensive analysis of these objectives. Based on available information, we consider four groups of motives for innovating: first, those oriented towards product innovation (e.g., improving the quality of services, increasing the range of services, and entering new markets); second, those oriented towards process innovation (improving flexibility of production or service provision, increasing production capacity and service provision, reducing unit labour costs, and reducing the consumption of materials and energy); third, those oriented towards reducing environmental impact; and, fourth, those directed towards compliance with environmental, health and safety regulations. The figures in Table 1 indicate that process innovation is recognized as being the most important innovation objective (high importance), but that the other objectives are also relevant.

Innovation strategies are not mutually exclusive. Firms can focus exclusively on one type (i.e., internal R\&D) or can conduct all three at the same time. Table 2 shows the frequency of multi-strategy use by energy firms; yet, it also indicates that $37.7 \%$ of firms do not 
perform any activity related to R\&D. $18.4 \%$ of firms report using only one strategy; in this case, the most frequently used strategy is internal R\&D (59\% of the total), followed by the acquisition of machinery, equipment and software (31\%) and external R\&D activities (10\%). However, when firms use two strategies simultaneously (which occurs in $35 \%$ of cases), the most frequently used pair of strategies is internal and external R\&D, observed in almost $80 \%$ of cases. Hence, although external R\&D activities are seldom adopted as an individual strategy, they are the most frequent complement of internal R\&D activities. Finally, only in $9.2 \%$ of cases do firms use all three strategies.

\section{Table 2}

\subsection{Model specification and variables}

To analyse the firms' decisions to invest in internal $R \& D$, external $R \& D$ and in the acquisition of advanced machinery, we use the following specification:

$D_{i}=\left\{\begin{array}{c}1 \text { if } \alpha_{i} D_{i}^{L}+\beta X+\gamma O+\delta C+\varepsilon_{i}>0 \\ 0 \text { otherwise }\end{array}\right.$

In this equation, $D_{i}$ corresponds to the dichotomous decision to engage or not in one of the three innovation activities considered $(i=1,2,3)$, and $D_{i}^{L}$ refers to its first time lag (since our estimations are based on pooled cross-sections, we can drop the time subscript. However, we simply distinguish the first lag of the dependent variable by the superscript L).

The independent variables in the estimations are the same. Our main goal is to analyse the role that the firms' innovation objectives $(\mathrm{O})$ have on the decisions of energy firms to invest in either internal $R \& D$, external $R \& D$ or advanced machinery. In the estimations we control for persistence in $R \& D$, including a lag of the dependent variable, and for the main firm characteristics $(\mathrm{X})$ that may explain the decisions taken by firms. In addition, we take into account the potential existence of cost barriers to innovation (C).

We include a set of variables which gather the objectives of innovation to examine the motives driving decisions to invest in each of the three categories. As previously stated in the data section, four groups of motives for innovating are considered: those oriented towards product innovation, towards process innovation, reducing environmental impact and those directed towards compliance with environmental, health and safety regulations. Firms are asked to report the degree of importance (not relevant, low, medium and high). Considering the self-reported nature of the answers we focus on our estimations on the firms that assess the objective to be of high importance. Then, vector $\mathrm{O}$ includes four different dummies that take the value 1 if the firm considers the innovation objective (product, process, environment, regulations) of high importance.

We include a lag of the dependent variable in each of the three estimations to control for potential persistence. Recent analyses have underlined the persistence of innovation activities and the important role that this persistence plays in long-run industry dynamics and firm economic performance (Arqué-Castells, 2013; Le Bas and Scellato, 2014; 
Raymond et al., 2010). The main reason for this persistence is that $R \& D$ activities present high degrees of cumulativeness and irreversibility. This evidence is supported by our data. The three main innovation activities are quite persistent. The transition probabilities for each strategy considered are high particularly for internal and external R\&D (80\% and $76 \%$ respectively).

Empirical studies on innovative activity have considered various theoretical approaches, such as a resource-based view and evolutionary economics, to choose firm characteristics that may explain $R \& D$ and innovation activity. In line with the literature on the determinants of the decision to engage in R\&D and innovation in general (Barge-Gil and López, 2014; Crepon et al., 1998; Cohen, 2010; Griffith et al., 2006), but also specifically in energy firms (Costa-Campi et al., 2014; Salies, 2010), we control for size, age, foreign capital, belonging to a group and public financing.

Since Schumpeter's seminal contribution, size has always been a key variable in the analysis of R\&D and innovation at the firm level. Large firms have more internal funds, they are more likely to engage in risky projects like $R \& D$ activities and there are economies of scale in R\&D investments (Barge-Gil and López, 2014, Raymond et al., 2010). Indeed, empirical findings for the energy sector show that larger firms are more likely to invest in internal R\&D (Costa-Campi et al., 2014; Jamasb and Pollitt, 2008; Salies, 2010; Sanyal and Cohen, 2009; Wang and Mogi, 2017).

A firm's age may also influence its decision to invest in R\&D and machinery. Recent papers show that the determinants of $R \& D$ investment are not the same for young firms as they are for older firms (García-Quevedo et al., 2014) with the former relying more heavily on the acquisition of machinery to innovate (Pellegrino et al., 2012). We also control for the participation of foreign investors in the firm and whether the firm belongs to a group of firms. Both characteristics may influence decisions to invest in R\&D and advanced machinery and have been frequently included in analyses of R\&D determinants.

We have included the variable of public funding to control for the effects of subsidies on R\&D and innovation decisions and to examine possible differences in their impact on the three innovation strategies. Public support is primarily targeted at the promotion of internal and external R\&D and not the acquisition of advanced machinery. Most empirical studies of the determinants of R\&D (Griffith et al., 2006; Hall et al., 2013) include it in their models. To minimise endogeneity concerns owing to the fact that public support is related to prior $R \& D$ and innovation performance, we conduct the estimations with the lag of this variable. To lag explanatory variables by one period is a common procedure employed when using data from the Community Innovation Survey (Barge-Gil and López, 2014) ${ }^{1}$.

A major obstacle to innovation are cost factors. Therefore, we have included this obstacle in order to examine whether this hampers $R \& D$ and innovation decisions and to determine

\footnotetext{
${ }^{1}$ Monfardini and Radice (2008) suggest that in the context of multivariate discrete choice models, the exogeneity condition for a given variable can be stated in terms of the correlation coefficient, which can be interpreted as the correlation between unobservable explanatory variables of any two equations. In our case, we have extended our triprobit model with a fourth equation for the lagged value of public funds. It turns out that the correlation coefficient of this equation with the other three is statistically zero, indicating that the lagged value of public funds is exogenous to all other equations. These results are not shown to save space but are available from the authors upon request.
} 
whether the effects differ across the three categories of innovation. Firms are asked to report the importance (not relevant, low, medium or high) of three different cost factors: lack of internal funds, lack of external funds and innovation costs being too high. Following the empirical literature on barriers to innovation (Pellegrino and Savona, 2017) we have grouped them. The variables takes the value 1 if the firm gives high importance to at least one of these obstacles. R\&D investments are characterised by the uncertainty of results and returns, which may account for the existence of financial constraints (Hall, 2002). Nevertheless, specific empirical analyses for the energy industry suggest that financial constraints and other cost factors are not a significant obstacle to innovation for firms in this industry (Salies, 2010; Costa-Campi et al., 2014).

Finally, and in addition to the explanatory variables, in the equations we take into account time effects in order to control for possible shocks arising from changes in the economic cycle as well as regulatory changes that may have affected the firms' $R \& D$ and innovation decisions.

\subsection{Methodology}

To carry out the estimations we use a trivariate probit model. For three binary variables $D_{1}, D_{2}$, and $D_{3}$, the trivariate probit model supposes that:

$$
\begin{aligned}
& D_{1}=\left\{\begin{array}{cc}
1 & \text { if } \alpha_{1} D_{1}^{L}+\beta X+\gamma O+\delta C+\varepsilon_{1}>0 \\
0 & \text { otherwise }
\end{array}\right. \\
& D_{2}=\left\{\begin{array}{cc}
1 & \text { if } \alpha_{2} D_{2}^{L}+\beta X+\gamma O+\delta C+\varepsilon_{2}>0 \\
0 & \text { otherwise }
\end{array}\right. \\
& D_{3}=\left\{\begin{array}{cc}
1 & \text { if } \alpha_{3} D_{3}^{L}+\beta X+\gamma O+\delta C+\varepsilon_{3}>0
\end{array}\right.
\end{aligned}
$$

with

$$
\left(\begin{array}{l}
\varepsilon_{1} \\
\varepsilon_{2} \\
\varepsilon_{3}
\end{array}\right) \rightarrow N(0, \Sigma)
$$

In this case, the evaluation of the likelihood function requires the computation of trivariate normal integrals. By way of example, consider the probability of observing $\left(D_{1}=0, D_{2}=\right.$ $\left.0, D_{3}=0\right)$ :

$$
\operatorname{Pr}\left[D_{1}=0, D_{2}=0, D_{3}=0\right]=\int_{-\infty}^{A_{1}} \int_{-\infty}^{A_{2}} \int_{-\infty}^{A_{3}} \phi_{3}\left(\varepsilon_{1}, \varepsilon_{2}, \varepsilon_{3}, \rho_{12} \rho_{13} \rho_{23}\right) \mathrm{d} \varepsilon_{3} \mathrm{~d} \varepsilon_{2} \mathrm{~d} \varepsilon_{1}
$$

where $A_{i}=\alpha_{0}+\alpha_{i} D_{i}^{L}+\beta X+\gamma O+\delta C, \phi_{3}$ is the trivariate normal p.d.f., and $\rho_{i j}$ is the correlation coefficient between $\mathrm{i}$ and $\mathrm{j}$. We rely on the triprobit command in Stata to perform the estimations, an estimation procedure that uses the GHK (Geweke- 
Hajivassiliou-Keane) smooth recursive simulator to approximate these integrals and estimate the coefficients by means of simulated maximum likelihood.

Multivariate binary models are well suited to analysing the determinants of the choices of economic agents. This methodology has been applied in different settings. For example, Carboni and Russu (2018) use firm-level data from seven European countries to analyse firms' decisions to conduct process, product, and organizational innovations. Similarly, in the energy sector Nakamura (2016) employs this methodology to study the factors that determine electricity saving behaviour based on a sample of Japanese households. The multivariate probit model used in this paper captures the impact of independent variables on multiple correlated binary dependent variables, while not imposing a priori constraints on the correlation of the error terms. However, except for the case of two binary dependent variables (the binary probit model or biprobit), there are no closed-form solutions to the integrals in the log-likelihood requiring the use of simulation methods.

\section{RESULTS AND DISCUSSION}

\subsection{Main results}

The results of the estimations reveal significant differences in the effects of the objectives of innovation on decisions to engage in the three innovation activities. R\&D, both internal and external, is strongly related with environmental motives and the goal of meeting regulatory requirements (environmental, health and safety) while process innovation objectives are related to the acquisition of advanced machinery.

First, the estimations show a significant positive relationship between the environmental objective of innovation and external R\&D, a result also found by Jakobsen and Clausen (2016) for firms in general. The relationship with internal R\&D is also positive but the evidence is weaker, with a lower significance level. This result suggests that to achieve their environmental innovation objectives firms resort to external resources to access new skills. This shows the importance for energy firms to establish relationships with $R \& D$ providers as a way to access the knowledge required to meet the challenges related to environmental innovations.

Second, there is a significant positive relationship between meeting regulatory requirements and internal $R \& D$, and also with external $R \& D$. From a demand-pull approach, regulation may cause a change in demand and induce $R \& D$ investments. Regulation has been found to be a significant factor influencing innovation. For ecoinnovations, in particular, regulation has been identified as a significant driver for the adoption and development of environmental technologies (Veugelers, 2012; del Río et al., 2015; del Río et al., 2016; Jové-Llopis and Segarra-Blasco, 2018).

A caveat regarding the importance of the environmental reasons to innovate is that the self-reported nature of the response may cast doubts about the reliability of the answers of the firms and whether they are not innovating mainly to meet regulations. Actually, there is a strong relationship between environmental objectives and innovation to meet regulatory requirements that it is corroborated by the high correlation (0.53) found between these two objectives in our data. To minimise this concern we have built the 
objective innovation indicator so that an answer only is only considered affirmative when the firms report that the objective is of high importance.

In addition, there is evidence that firms, and particularly major corporations, voluntarily over-comply with environmental regulations to show that they are environmentally concerned and they take into account the criteria of smart investors and stakeholders (Konar and Cohen, 2001). Recent work (Benerjee and Gupta, 2018) shows that mandatory compliance with environmental regulations as well as voluntary adoption of environmental sustainability practices have a positive effect on R\&D intensity in firms. Customer expectations and voluntary agreements have also been found to positively affect the likelihood of firms to eco-innovate (Doran and Ryan, 2016). Our estimations show that even when controlling for regulation motives, environmental objectives are positively related with $R \& D$ in energy firms.

Third, the goal of introducing process innovations has no positive effects on R\&D but it is the main factor in the acquisition of advanced machinery. This result shows that energy firms adopt technological advances by acquiring machinery from suppliers. As Sanyal and Cohen (2009) point out, suppliers of energy equipment have generated most of the innovations made in the energy sector. Estimations using the specific process innovation objectives (as opposed to the whole category) show that increasing capacity and improving flexibility of production are the two main reasons for innovating when implementing a new or significantly improved production process ${ }^{2}$. The results also show that introducing product innovations, new or improved services, has a positive effect, although with a lower significance level, on the decision of the firms to invest in advanced machinery. Investments connected with the digital transformation of the industry may explain this result.

\section{Table 3}

Regarding the other variables, the estimations show the persistence of $R \& D$ decisions in energy firms. This persistence also occurs in investments in advanced machinery, which suggests that innovation in energy firms requires a continuous flow of capital expenditure to improve the technological standards of their equipment.

The results for the variables that control firms' characteristics show significant differences across the three innovation activities. First, larger firms in this sector are more likely to invest in internal $R \& D$ and to acquire R\&D services. In contrast, size is not significant in the acquisition of advanced machinery. This result confirms the importance of firm size in undertaking $R \& D$ projects, while firms of all sizes acquire advanced machinery as a way of updating their technological standards. Second, age does not seem to have a significant influence on R\&D and innovation decisions. Third, public funds do not have a positive effect on the decision to invest in R\&D or in advanced machinery. The results also confirm previous evidence indicating that cost factors are not a major barrier to innovation in the energy industry (Salies, 2010; Costa-Campi, 2014).

Finally, the results also point to the possible existence of complementarities between internal and external R\&D. In the three sets of estimations, the correlation coefficients of the error terms are positive and highly significant. In line with the recent literature on

\footnotetext{
${ }^{2}$ Those results are not shown to save space but are available from the authors upon request.
} 
R\&D decisions, these results support the existence of interdependencies between undertaking internal $R \& D$ and acquiring $R \& D$ services. In contrast, there is no such interdependence between the decisions to perform $R \& D$ and the acquisition of advanced machinery. Indeed, the decision as to whether to invest in R\&D or in advanced machinery is an independent one, which again suggests that the two activities pursue different innovation objectives. However, caution must be exercised in this analysis of potential interdependence, since we do not formally test the existence of complementarities. Moreover, the correlations may also be found if there are unobservable firm-specific factors affecting R\&D and innovation decisions.

\subsection{Extensions of the baseline model and robustness checks}

The results of the previous subsection highlight some of the factors behind the decisions by firms to perform each type of $R \& D$ activity and indicate the existence of complementarities between internal and external R\&D strategies. In this subsection, we explore some extensions of the baseline specification, so as both to expand our understanding of some of the issues associated with innovation strategies in the energy sector and to check the consistency of the baseline results.

When dealing with firm-level data, controlling for individual effects is important to capture any heterogeneity in the decision-making process of the different production units. Unfortunately, the triprobit specification used here is unable to capture these individual effects. Therefore, to test whether firm heterogeneity is relevant in the determination of the optimal innovation strategy, we estimate three independent random effects panel probit regressions - one for each decision. This approach allows us to assess whether individual effects play a relevant role in the different R\&D strategies and, in particular, whether they have an effect on the complementarity between them. Table 4 presents the results. It can be seen from the table that the results obtained are consistent with the main conclusions from the baseline model and, hence, we can safely conclude that the omission of individual effects from the triprobit baseline specification is not driving the results.

As a second extension, in each equation we include not only the lagged dependent variable to test for persistence in $R \& D$ activities, but also the lagged dependent variables of the other two dependent variables of the triprobit system. Similarly to the empirical analyses (Arqué-Castells, 2013; Raymond et al., 2010) that examine persistence in R\&D and innovation activities, we use only one lag for the other dependent variables. Nevertheless, the effects between these variables could require longer periods. To analyse these time effects accurately would be data demanding and would require a longer panel of data. The purpose of this specification is to detect the direction of the complementarity beyond persistence, i.e., does the fact of having invested in some type of innovation activity in time period $t-1$ increase the probability of investing in some other type of innovation in time period $t$ ? The results, shown in Table 5, indicate first that innovation persistence by type of innovation activity is preserved when we introduce additional lagged variables. In addition, all the main results obtained in the baseline model are maintained. Second, the table provides weak evidence of substitutability with a negative coefficient of lagged internal $R \& D$ expenditure in the machinery equation. There is no other direction of complementarity or substitutability that is statistically significant. 
Finally, we include a fourth equation in the multivariate probit system in order to capture a fourth strategic choice, namely disembodied technological change. This includes the acquisition - or use under license - of patents or non-patented inventions and technological knowledge to be used in the innovation process of the acquiring company. Although only $6 \%$ of the firms in our sample use this strategy, exploring how disembodied technological change is related to more traditional strategies is relevant. The results are presented in Table 6. First, it is shown that the results of the baseline model are preserved. Second, we find that persistence is also significant in the case of disembodied technological change. Third, the probability of spending on this type of knowledge acquisition is mostly explained by the objective of reducing environmental impacts. Finally, we also detect strong complementarities between disembodied technological change and external R\&D strategies.

In short, our extensions corroborate the robustness of the results obtained from the baseline model. This means that we can safely conclude that environmental motives and regulatory requirements mostly affect the probability of incurring spending on internal and external R\&D. Reducing environmental impacts also affects the probability of performing disembodied technological change strategies, while the process innovation objective is the main factor in the acquisition of advanced machinery. In addition, the results show that energy firms perform $R \& D$ persistently, that a larger size influences the probability of it performing internal and external R\&D and that cost factors do not represent a relevant obstacle to innovation in this industry.

Table 4

Table 5

Table 6

\section{CONCLUSIONS}

The energy industry is undergoing a major transformation together with substantial technological change that is leading to an increasing need to perform $R \& D$. Investment in innovation is considered essential to improve energy efficiency and competitiveness and for facing the challenges of climate change.

This paper has sought to shed further light on the innovation activities of energy firms. We have analysed the role that various innovation objectives play in the decisions of energy firms to invest in R\&D and innovation. For this analysis, we have used the three main innovation activities: internal $R \& D$, external $R \& D$ and the acquisition of advanced machinery.

Our results reveal significant differences in the effects that the objectives sought by innovation have on decisions to engage in one or more of the three innovation activities. While internal and external $R \& D$ are undertaken to address environmental objectives and to fulfil regulatory requirements, the aim of developing process innovations is the main driver of the acquisition of advanced machinery and equipment. In a context of increasing requirements for $\mathrm{R} \& \mathrm{D}$ activities in the energy industry, regulation seems to be an 
important factor driving internal $R \& D$ while the environmental objective of innovation is also achieved through internal R\&D but mainly by acquiring R\&D services.

These results suggest that $R \& D$ and the acquisition of advanced machinery address different technological and market challenges. Specifically, they highlight that R\&D projects are required in order to meet the objective of reducing environmental impacts and regulatory requirements. This goal cannot be achieved with the introduction of new machinery and equipment that is geared towards process innovation objectives.

Our results point to the existence of interdependencies between undertaking internal R\&D and acquiring R\&D services. This result suggests that there are efficiency gains when these two activities are carried out together. In contrast, decisions as to whether to invest in R\&D or in advanced machinery seem to be independent; moreover, they appear to address different technological challenges.

The econometric estimations also show that investments in innovation are highly persistent. This persistence is evident not only in the case of internal and external R\&D decisions but also in the acquisition of advanced machinery. Second, the characteristics of the energy firms that opt to engage in each of these innovation activities differ. In particular, large firms are more likely to invest in internal and external R\&D while size is found not to be significant in the estimation for the acquisition of advanced machinery. Third, costs factors (financial constraints and high innovation costs) do not seem to be a major barrier in the energy industry to engagement in innovation.

In this paper, we have analysed the decisions to undertake different types of innovation activities. However, a limitation of this approach is that we do not analyse the proportion of resources that firms devote to each one of these activities. Although we consider this as an interesting issue, the empirical methodology required is beyond the scope of this paper. For that case, a sample selection issue arises since the proportion of innovation resources devoted to each type of innovation is only observed if the firm has decided to invest. Given that we are dealing with three different decision variables, this would imply a multi-dimensional selection problem. While to the best of our knowledge this has been solved for dichotomous variables both in the selection and intensity equations, it is not straightforward in the case of continuous intensity variables. We leave this issue for future research.

The outcomes of this study have a number of policy implications, especially, as regards how best to foster innovation in the energy industry. Traditional energy business models have been eroded and now energy firms are forced to refine their innovation business strategy in accordance with new environmental challenges. The transition towards a netzero greenhouse economy gives to the energy sector a central role at addressing climate change. Our results suggest that the need to adhere to environmental regulations is positively related with the R\&D activity of private firms. Then, successful green technologies may lead to other benefits such as cost savings, enhanced corporate image, improve allow access to new green markets and creation of new markets among others. 
Anadon, L., Bunn, M., Chan, G., Chan, M., Jones, C., Kempener, R., Lee, A., Logar, N., Narayanamurti, V. (2011). Transforming U.S. energy innovation. Energy Technology Innovation Policy research group. Belfer Center for Social and International Affairs, Harvard Kennedy School, Cambridge, MA.

Arqué-Castells, P. (2013). Persistence in R\&D performance and its implications for the granting of subsidies. Review of Industrial Organization 43, 193-220.

Blanchard, P., Huiban, J.P., Musolesi, A.; \& Sevestre, P. (2013). Where there is a will, there is a way? Assessing the impact of obstacles to innovation. Industrial and Corporate Change 22, 679-710.

Banerjee, R., \& Gupta, K. (2018). The effect of environmental sustainable practices on firm R\&D: International evidence. Economic Modelling, https://doi.org/10.1016/j.econmod.2018.09.024 (in press).

Barge-Gil., \& López, A. (2014). R\&D determinants: Accounting for the differences between research and development. Research Policy 43, 1634-1648.

Bointner, R. (2014). Innovation in the energy sector: Lessons learnt from R\&D expenditures and patents in selected IEA countries. Energy Policy 73, 733-747.

Bönte, W., \& Dienes, C. (2013). Environmental innovations and strategies for the development of new production technologies: empirical evidence from Europe. Business Strategy and the Environment 22, 501-516.

Boons, F., \& Lüdeke-Freund, F. (2013). Business models for sustainable innovation: state-of-the-art and steps towards a research agenda. Journal of Cleaner production 45, 919.

Cassiman, B., \& Veugelers, R. (2006). In search of complementarity in innovation strategy: internal R\&D and external R\&D acquisition. Management Science 52, 68-82.

Catozzella, A.,\& Vivarelli, M. (2014). The catalysing role of in-house R\&D in fostering complementarity among innovative inputs. Industry and Innovation 21, 179-196.

Carboni, O. A., \& Russu, P. (2018). Complementarity in product, process, and organizational innovation decisions: evidence from European firms. R\&D Management 48, 210-222.

Cohen, L., \& Sanyal, P. (2008). R\&D choice in restructured industries: In-house v/s collaborative research in the US electricity industry. Working Paper SSRN Electronic Journal 03/2008. DOI: 102139/ssrn.556645.

Cohen, W., 2010. Fifty years of empirical studies of innovative activity and performance, in: Hall, B., Rosenberg, N. Handbook of the Economics of Innovation, Elsevier, pp. 129213.

Costa-Campi, M.T., Duch-Brown, N., \& García-Quevedo, J. (2014). R\&D drivers and obstacles to innovation in the energy industry, Energy Economics 46, 20-30

Costa-Campi, M.T., García-Quevedo, J., \& Trujillo, E. (2015a). Challenges for R\&D and innovation in energy. Energy Policy 83, 193-196.

Costa-Campi, M.T., García-Quevedo, J., \& Segarra, A. (2015b). Energy efficiency determinants: An empirical analysis of Spanish innovative firms. Energy Policy 83, 197205.

Costa-Campi, M.T., García-Quevedo, J., \& Martínez-Ros, E. (2017). What are the determinants of investment in environmental R\&D? Energy Policy 104, 455-465.

Crepon, B., Duguet, E., \& Mairesse, J. (1998). Research, innovation and productivity: an econometric analysis at the firm level. Economics of Innovation and New Technology 7, 115-158. 
Cruz-Cázares, C., Bayona-Sáez, C., \& García-Marco, T. (2013). Make, buy or both? R\&D strategy selection. Journal of Engineering and Technology Management 30, 227245.

Daim, T. U., Oliver, T., \& Iskin, I. (2013). Research and development (R\&D) portfolio management in the electric utility sector: Does it change for the service sector? Benchmarking: An International Journal 20, 186-211.

D'Este, P., Iammarino, S., Savona, M., \& von Tunzelmann, N. (2012). What hampers innovation? Revealed barriers versus deterring barriers. Research Policy 41, 482-488.

De Marchi, V. (2012). Environmental innovation and R\&D cooperation: Empirical evidence from Spanish manufacturing firms. Research Policy 41, 614-623.

Del Río, P., Peñasco, C., Romero-Jordán, D., 2015. Distinctive features of environmental innovators: An econometric analysis. Business Strategy and the Environment 24, 361385.

Del Río, P., Peñasco, C., \& Romero-Jordán, D. (2016). What drives eco-innovators? A critical review of the empirical literature based on econometric methods. Journal of Cleaner Production, 112, 2158-2170.

Doran, J., Ryan, G. (2016). The importance of the diverse drivers and types of environmental innovation for firm performance. Business Strategy and the Environment 25, 102-119.

Eurelectric (2013). Utilities: Powerhouses of Innovation. Full Report, Brussels, May 2013.

Gallagher, K., Grübler, A., Kuhl, L. Nemet, G., \& Wilson, Ch. (2102). The energy technology innovation system. Annual Review of Environmental Resources 37, 137-162. García-Quevedo, J., Pellegrino, G., \& Vivarelli, M. (2014). R\&D drivers and age? Are young firms different? Research Policy 43, 1544-1556.

GEA (2012). Global Energy Assessment. Towards a sustainable future, Cambridge University Press, Cambridge, UK and New York, USA.

Griffith, R., Huergo, E., Mairesse, J., \& Peters, B. (2006). Innovation and productivity across four European Countries. Oxford Review of Economic Policy 22, 483-498.

Hall, B. (2002). The financing of research and development. Oxford Review of Economic Policy 18, 37-51.

Hall, B., Lotti, F., \& Mairesse, J. (2013). Evidence on the impact of R\&D and ICT investments on innovation and productivity in Italian firms. Economics of Innovation and New Technology 22, 300-328.

Horbach, J. (2008). Determinants of environmental innovation-new evidence from German panel data sources. Research policy 37, 163-173.

IRENA (2018). Power system flexibility for the energy transition. International Renewable Energy Agency, Abu Dhabi.

Jacquier-Roux, V., \& Bourgeois, B. (2002). New networks of technological creation in energy industries: reassessment of the roles of equipment suppliers and operators. Technology analysis \& strategic management 14, 399-417.

Jakobsen, S., \& Clausen, T. (2016). Innovating for a greener future: the direct and indirect effect of firms' environmental objectives on the innovation process. Journal of Cleaner Production 128, 131-141.

Jamasb, T., \& Pollitt, M. (2008). Liberalisation and R\&D in network industries: The case of the electricity industry. Research Policy 37, 995-1008.

Jamasb, T., \& Pollitt, M. (2015). Why and how to subsidise energy R\&D: Lessons from the collapse and recovery of energy innovation in the UK. Energy Policy 83, 197-205. 
Jové-Llopis, E., \& Segarra-Blasco, A. (2016). What is the Role of Innovation Strategies? Evidence from Spanish Firms (September 30, 2016). XREAP2016-03. Available at SSRN: https://ssrn.com/abstract=2845894.

Jové-Llopis, E., \& Segarra-Blasco, A. (2018). Eco-innovation strategies: A panel data analysis of Spanish manufacturing firms. Business Strategy and the Environment 27, 1209-1220.

Klose, F., Kofluk, M., Lehrke, S., \& Rubner, H. (2010). Toward a distributed-power world. Renewables and smart grids will reshape the energy sector. The Boston Consulting Group Report.

Konar, S., \& Cohen, M. (2001). Does the market value environmental performance?. The Review of Economics and Statistics 83, 281-289.

Le Bas, Ch., \& Scellato, G. (2014). Firm innovation persistence: a fresh look at the frameworks of analysis. Economics of Innovation and New Technology 23, 423-446.

Leiponen, A., \& Helfat, C.E. (2010). Innovation Objectives, Knowledge Sources and the Benefits of Breadth, Strategic Management Journal, 31, 224-236.

Mairesse, J., \& Mohnen, P. (2010). Using innovation surveys for econometric analysis, in: Hall, B., \& Rosenberg, N. (Eds), Handbook of the Economics of Innovation, Elsevier, pp. $1129-1155$.

Monfardini, C., \& Radice, R. (2008). Testing exogeneity in the bivariate probit model: a Monte Carlo Study. Oxford Bulletin of Economics and Statistics 70(2), 271-282.

Nakamura, E. (2016). Electricity saving behavior of households by making efforts, replacing appliances, and renovations: empirical analysis using a multivariate ordered probit model. International Journal of Consumer Studies 40, 675-684

Narula, R. (2001). Choosing between internal and non-internal R\&D activities: some technological and economic factors. Technology Analysis \& Strategic Management 13, 365-387.

Nelson, R.R., \& Winter, S.G. (1982). An evolutionary theory of economic change. Cambridge, MA: Harvard University Press.

OECD (2005). Oslo Manual. The measurement of scientific and technological activities. Proposed guidelines for collecting and interpreting technological innovation data. $3^{\text {rd }}$ Edition. OECD Publishing.

OECD (2011). Fostering innovation for green growth. Organisation for Economic Cooperation and Development, Paris.

Osterwalder, A., \& Pigneur, Y. (2010). Business Model Generation: a Handbook for Visionaries, Game Changers, and Challengers. John Wiley \& Sons.

Pellegrino, G., Piva, M., \& Vivarelli, M. (2012). Young firms and innovation: A microeconometric analysis. Structural Change and Economic Dynamics 23, 329-340.

Pellegrino, G., \& Savona, M. (2017). No money, no honey? Financial versus knowledge and demand constraints to innovation. Research Policy 46, 510-521.

Pérez-Arriaga, I., Jenkins, D., \& Batlle, C. (2017). A regulatory framework for an evolving electricity sector: Highlights of the MIT utility of the future study. Economics of Energy \& Environmental Policy 6, 71-92.

Popp, D., \& Newell, R. (2012). Where does energy R\&D come from? Examining crowding out from energy R\&D. Energy Economics 34, 980-991.

Raymond, W. Mohnen, P. Palm, F., \& van der Loeff, S. (2010). Persistence of Innovation in Dutch Manufacturing: Is It Spurious? Review of Economics and Statistics 92, 495-504. Richter, M. (2013). Business model innovation for sustainable energy: German utilities and renewable energy. Energy Policy 62, 1226-1237. 
Rayna, T., \& Striukova, L. (2016). Involving Consumers: The Role of Digital Technologies in Promoting 'Prosumption' and User Innovation. Journal of the Knowledge Economy, 1-20. https://doi.org/10.1007/s13132-016-0390-8.

Richter, M. (2013). Business model innovation for sustainable energy: German utilities and renewable energy. Energy Policy 62, 1226-1237

Salies, E. (2010). A test of the Schumpeterian hypothesis in a panel of European Electric Utilities, in: J.L Gaffard, J.L., \& Salies, E., Innovation, Economic Growth and the Firm. Edward Elgar Publishing.

Sanyal, P., \& Cohen, L. R. (2009). Powering Progress: Restructuring, Competition, and R\&D in the U.S. Electric Utility Industry. The Energy Journal 30, 41-79.

Savignac, F. (2008). Impact of Financial Constraints on Innovation: What Can Be Learned from a Direct Measure? Economics of Innovation and New Technology 17, 55369.

Schumpeter, J. (1942). Capitalism, Socialism and Democracy. Harper and Brothers, New York.

Sterlacchini, A. (2012). Energy R\&D in private and state-owned utilities: An analysis of the major world electric companies. Energy Policy 41, 494-506.

Wangler, L. U. (2013). Renewables and innovation: did policy induced structural change in the energy sector effect innovation in green technologies? Journal of Environmental Planning and Management 56, 211-237.

Veugelers, R., \& Cassiman, B. (1999). Make and buy in innovation strategies: evidence from Belgian manufacturing firms. Research Policy 28, 63-80.

Veugelers, R. (2012). Which policy instruments to induce clean innovating? Research Policy 14, 1770-1778.

Wang, N., \& Mogi, G. (2017). Deregulation, market competition, and innovation of utilities: Evidence from Japanese electric sector. Energy Policy 111, 403-413.

Wiesenthal, T., Leduc, G., Haegeman, K., \& Schwarz, H. G. (2012). Bottom-up estimation of industrial and public R\&D investment by technology in support of policymaking: The case of selected low-carbon energy technologies. Research Policy 41, 116131. 
Table 1: Descriptive statistics

\begin{tabular}{|c|c|c|c|c|c|c|}
\hline Variable & Description & $\mathbf{N}^{\mathbf{o}}$ & Mean & Std. Dev. & Min & Max \\
\hline \multicolumn{7}{|l|}{ Dependent variables } \\
\hline & Dummy $=1$ if the firm has invested in internal & & & & & \\
\hline Internal R\&D & $\mathrm{R} \& \mathrm{D}$ & 653 & 0.522 & 0.500 & 0 & 1 \\
\hline External R\&D & Dummy $=1$ if the firm has acquired external $R \& D$ & 653 & 0.413 & 0.493 & 0 & 1 \\
\hline Machinery, equipment or software & $\begin{array}{l}\text { Dummy }=1 \text { if the firm has invested in the } \\
\text { acquisition of machinery, equipment and software } \\
\text { Dummy }=1 \text { if the firm has purchased or licensed }\end{array}$ & 653 & 0.219 & 0.414 & 0 & 1 \\
\hline Disembodied technical change & patents, non-patented inventions and know-how & 653 & 0.057 & 0.231 & 0 & 1 \\
\hline \multicolumn{7}{|l|}{ Independent variables } \\
\hline Size & Number of employees & 653 & 619.0 & 1046.6 & 1 & 7900 \\
\hline Age & Years the firm has been operating in the market & 594 & 34.6 & 33.5 & 0 & 116 \\
\hline Public funds & $\begin{array}{l}\text { Dummy }=1 \text { if the firm has received an } R \& D \\
\text { subsidy }\end{array}$ & 653 & 0.421 & 0.494 & 0 & 1 \\
\hline Foreign capital & Dummy $=1$ if the firm belongs to a group of firms & 653 & 0.214 & 0.411 & 0 & 1 \\
\hline Group & $\begin{array}{l}\text { Dummy = } 1 \text { if the firm considers this innovation } \\
\text { objective of high importance } \\
\text { Dummy = } 1 \text { if the firm considers this innovation }\end{array}$ & 653 & 0.686 & 0.464 & 0 & 1 \\
\hline Product & $\begin{array}{l}\text { objective of high importance } \\
\text { Dummy }=1 \text { if the firm considers this innovation }\end{array}$ & 653 & 0.401 & 0.491 & 0 & 1 \\
\hline Process & $\begin{array}{l}\text { objective of high importance } \\
\text { Dummy }=1 \text { if the firm considers this innovation }\end{array}$ & 653 & 0.436 & 0.496 & 0 & 1 \\
\hline Environment & $\begin{array}{l}\text { objective of high importance } \\
\text { Dummy }=1 \text { if the firm considers this innovation }\end{array}$ & 653 & 0.323 & 0.468 & 0 & 1 \\
\hline Regulations & $\begin{array}{l}\text { objective of high importance } \\
\text { Dummy = } 1 \text { if the firm considers cost barriers of }\end{array}$ & 653 & 0.250 & 0.433 & 0 & 1 \\
\hline Cost barriers & high importance & 653 & 0.100 & 0.300 & 0 & 1 \\
\hline
\end{tabular}


Table 2: Frequency of multi-strategy use

\begin{tabular}{cccccc}
\hline $\mathbf{N}^{\mathbf{0}}$ of strategies & Freq. & Percent & Internal RD & External RD & Machinery \\
\hline 0 & 246 & $37.7 \%$ & $0 \%$ & $0 \%$ & $0 \%$ \\
1 & 120 & $18.4 \%$ & $59 \%$ & $10 \%$ & $31 \%$ \\
2 & 227 & $34.8 \%$ & $93 \%$ & $87 \%$ & $20 \%$ \\
3 & 60 & $9.2 \%$ & $100 \%$ & $100 \%$ & $100 \%$ \\
\hline
\end{tabular}


Table 3: Triprobit estimation with characteristics, objectives, cost barrier and lagged dependent variables

\begin{tabular}{|c|c|c|c|}
\hline & $\begin{array}{c}(1) \\
\text { IntRD }\end{array}$ & $\begin{array}{c}(2) \\
\text { ExtRD }\end{array}$ & $\begin{array}{c}\text { (3) } \\
\text { Machinery }\end{array}$ \\
\hline Lag of dependent & $\begin{array}{c}2.232 * * * * \\
(0.209)\end{array}$ & $\begin{array}{c}1.992 * * * \\
(0.177)\end{array}$ & $\begin{array}{c}0.819 * * * \\
(0.151)\end{array}$ \\
\hline Size (in logs) & $\begin{array}{c}0.326 * * * \\
(0.0657)\end{array}$ & $\begin{array}{c}0.248 * * * \\
(0.0609)\end{array}$ & $\begin{array}{l}-0.00443 \\
(0.0470)\end{array}$ \\
\hline Age (in logs) & $\begin{array}{l}-0.0532 \\
(0.0919)\end{array}$ & $\begin{array}{c}0.0433 \\
(0.0867)\end{array}$ & $\begin{array}{c}0.0329 \\
(0.0711)\end{array}$ \\
\hline Public funds (t-1) & $\begin{array}{c}0.344 \\
(0.216)\end{array}$ & $\begin{array}{l}0.0996 \\
(0.192)\end{array}$ & $\begin{array}{c}0.00178 \\
(0.157)\end{array}$ \\
\hline Foreign capital & $\begin{array}{c}0.313 \\
(0.214)\end{array}$ & $\begin{array}{c}0.427 * * \\
(0.189)\end{array}$ & $\begin{array}{c}0.186 \\
(0.161)\end{array}$ \\
\hline Group & $\begin{array}{c}-0.0318 \\
(0.227)\end{array}$ & $\begin{array}{l}-0.0345 \\
(0.222)\end{array}$ & $\begin{array}{c}0.318 \\
(0.202)\end{array}$ \\
\hline Product & $\begin{array}{c}0.233 \\
(0.210)\end{array}$ & $\begin{array}{l}-0.171 \\
(0.194)\end{array}$ & $\begin{array}{l}0.271^{*} \\
(0.156)\end{array}$ \\
\hline Process & $\begin{array}{l}-0.138 \\
(0.220)\end{array}$ & $\begin{array}{l}0.0899 \\
(0.190)\end{array}$ & $\begin{array}{c}0.469 * * * \\
(0.169)\end{array}$ \\
\hline Environment & $\begin{array}{l}0.415^{*} \\
(0.224)\end{array}$ & $\begin{array}{c}0.666^{* * *} * \\
(0.207)\end{array}$ & $\begin{array}{r}-0.0225 \\
(0.189)\end{array}$ \\
\hline Regulations & $\begin{array}{c}0.589 * * \\
(0.241)\end{array}$ & $\begin{array}{c}0.499 * * \\
(0.216)\end{array}$ & $\begin{array}{l}-0.137 \\
(0.189)\end{array}$ \\
\hline Cost barrier & $\begin{array}{r}-0.0912 \\
(0.341)\end{array}$ & $\begin{array}{c}0.156 \\
(0.315)\end{array}$ & $\begin{array}{l}-0.256 \\
(0.264)\end{array}$ \\
\hline Constant & $\begin{array}{c}-2.707 * * * \\
(0.549)\end{array}$ & $\begin{array}{c}-2.447 * * * \\
(0.520)\end{array}$ & $\begin{array}{l}-0.411 \\
(0.407)\end{array}$ \\
\hline $\operatorname{athrho}_{(\text {IntRD-ExtRD })}$ & & $\begin{array}{c}0.770 * * * \\
(0.187)\end{array}$ & \\
\hline $\operatorname{athrho}_{(\text {IntRD-Machinery) }}$ & & $\begin{array}{l}-0.159 \\
(0.129)\end{array}$ & \\
\hline $\operatorname{athrho}_{(\text {ExtRD-Machinery })}$ & & $\begin{array}{l}-0.0736 \\
(0.0579)\end{array}$ & \\
\hline
\end{tabular}

The number of observations is 535. The Table shows the estimated coefficients and the standard errors (in parentheses). $* * *, * *$, and $*$ denote significance at the $1 \%, 5 \%$, and $10 \%$ levels, respectively. All regressions include time-dummies to control for year-specific effects. The multivariate probit (assuming normality of the error terms) provides with $\rho$, a correlation parameter that informs about the covariation of the error terms of the two decisions. If $\rho=0$, the probability of one decision is independent of the probability of the other decision. 


\begin{tabular}{lccc}
\hline & $(1)$ & $(2)$ & $(3)$ \\
& IntRD & ExtRD & Machinery \\
\hline \multirow{2}{*}{ Lag of dependent } & $2.291^{* * *}$ & $1.832^{* * *}$ & $0.675^{* * *}$ \\
Size (in logs) & $(0.211)$ & $(0.245)$ & $(0.186)$ \\
& $0.326^{* * *}$ & $0.306^{* * *}$ & 0.00501 \\
Age (in logs) & $(0.0673)$ & $(0.0911)$ & $(0.0588)$ \\
& -0.0546 & 0.0535 & 0.0416 \\
Public funds (t-1) & $(0.0942)$ & $(0.107)$ & $(0.0927)$ \\
Foreign capital & 0.317 & 0.147 & 0.0228 \\
& $(0.218)$ & $(0.227)$ & $(0.178)$ \\
Group & $0.355^{*}$ & $0.437 * *$ & 0.124 \\
& $(0.211)$ & $(0.222)$ & $(0.196)$ \\
Product innovation & -0.000716 & -0.0570 & 0.409 \\
Process innovation & $(0.231)$ & $(0.266)$ & $(0.251)$ \\
Environmental impact & 0.269 & -0.128 & 0.276 \\
Regulations & $(0.212)$ & $(0.206)$ & $(0.180)$ \\
Cost barrier & -0.156 & 0.0438 & $0.550 * * *$ \\
& $(0.220)$ & $(0.215)$ & $(0.193)$ \\
Constant & 0.318 & $0.707 * * *$ & -0.0274 \\
& $(0.229)$ & $(0.227)$ & $(0.206)$ \\
& $0.663^{* * *}$ & $0.467 *$ & -0.0639 \\
& $(0.243)$ & $(0.245)$ & $(0.208)$ \\
& -0.227 & 0.0153 & -0.295 \\
& $(0.341)$ & $(0.317)$ & $(0.287)$ \\
& $-2.785^{* * *}$ & $-2.818^{* * *}$ & -0.545 \\
& $(0.561)$ & $(0.679)$ & $(0.479)$ \\
& & &
\end{tabular}

The number of observations is 535 , and the number of firms is 62 . The Table shows the estimated coefficients and the standard errors (in parentheses). ***,**, and * denote significance at the $1 \%, 5 \%$, and $10 \%$ levels, respectively. All regressions include time-dummies to control for year-specific effects. The number of observations is 431 . The number of firms is 59 . 


\begin{tabular}{|c|c|c|c|}
\hline & $\begin{array}{c}(1) \\
\text { IntRD }\end{array}$ & $\begin{array}{c}(2) \\
\text { ExtRD } \\
\end{array}$ & $\begin{array}{c}(3) \\
\text { Machinery }\end{array}$ \\
\hline IntRD (t-1) & $\begin{array}{c}2.201 * * * \\
(0.227)\end{array}$ & $\begin{array}{c}0.294 \\
(0.224)\end{array}$ & $\begin{array}{l}-0.376^{*} \\
(0.204)\end{array}$ \\
\hline $\operatorname{ExtRD}(\mathrm{t}-1)$ & $\begin{array}{c}0.305 \\
(0.227)\end{array}$ & $\begin{array}{c}1.952 * * * \\
(0.192)\end{array}$ & $\begin{array}{c}0.144 \\
(0.178)\end{array}$ \\
\hline Machinery (t-1) & $\begin{array}{c}-0.0786 \\
(0.224)\end{array}$ & $\begin{array}{c}0.359^{*} \\
(0.198)\end{array}$ & $\begin{array}{c}0.814 * * * \\
(0.154)\end{array}$ \\
\hline Size (in logs) & $\begin{array}{c}0.311 * * * \\
(0.0670)\end{array}$ & $\begin{array}{c}0.239 * * * \\
(0.0632)\end{array}$ & $\begin{array}{c}0.0150 \\
(0.0494)\end{array}$ \\
\hline Age (in logs) & $\begin{array}{l}-0.0372 \\
(0.0936)\end{array}$ & $\begin{array}{c}0.0357 \\
(0.0886)\end{array}$ & $\begin{array}{c}0.0166 \\
(0.0728)\end{array}$ \\
\hline Public funds (t-1) & $\begin{array}{c}0.260 \\
(0.222)\end{array}$ & $\begin{array}{l}-0.0297 \\
(0.221)\end{array}$ & $\begin{array}{c}0.149 \\
(0.194)\end{array}$ \\
\hline Foreign capital & $\begin{array}{c}0.299 \\
(0.220)\end{array}$ & $\begin{array}{c}0.390 * * \\
(0.192)\end{array}$ & $\begin{array}{c}0.196 \\
(0.164)\end{array}$ \\
\hline Group & $\begin{array}{c}-0.00496 \\
(0.236)\end{array}$ & $\begin{array}{l}-0.100 \\
(0.229)\end{array}$ & $\begin{array}{c}0.301 \\
(0.204)\end{array}$ \\
\hline Product innovation & $\begin{array}{c}0.258 \\
(0.212)\end{array}$ & $\begin{array}{l}-0.173 \\
(0.194)\end{array}$ & $\begin{array}{l}0.268^{*} \\
(0.159)\end{array}$ \\
\hline Process innovation & $\begin{array}{l}-0.160 \\
(0.221)\end{array}$ & $\begin{array}{c}0.108 \\
(0.193)\end{array}$ & $\begin{array}{c}0.445 * * \\
(0.174)\end{array}$ \\
\hline Environmental impact & $\begin{array}{c}0.359 \\
(0.231)\end{array}$ & $\begin{array}{c}0.695 * * * \\
(0.209)\end{array}$ & $\begin{array}{l}-0.0519 \\
(0.194)\end{array}$ \\
\hline Regulations & $\begin{array}{c}0.571 * * \\
(0.244)\end{array}$ & $\begin{array}{c}0.453 * * \\
(0.221)\end{array}$ & $\begin{array}{c}-0.0746 \\
(0.194)\end{array}$ \\
\hline Cost barrier & $\begin{array}{l}-0.170 \\
(0.348)\end{array}$ & $\begin{array}{c}0.137 \\
(0.312)\end{array}$ & $\begin{array}{l}-0.237 \\
(0.264)\end{array}$ \\
\hline Constant & $\begin{array}{c}-2.718 * * * \\
(0.554)\end{array}$ & $\begin{array}{c}-2.440 * * * \\
(0.525)\end{array}$ & $\begin{array}{l}-0.353 \\
(0.411)\end{array}$ \\
\hline $\operatorname{athrho}_{(\operatorname{IntRD}-E x t R D)}$ & & $\begin{array}{c}0.796 * * * \\
(0.182)\end{array}$ & \\
\hline $\operatorname{athrho}_{(I n t R D-M a c h i n e r y)}$ & & $\begin{array}{l}-0.151 \\
(0.127)\end{array}$ & \\
\hline $\operatorname{athrho}_{(E x t R D-M a c h i n e r y)}$ & & $\begin{array}{l}-0.0774 \\
(0.0548)\end{array}$ & \\
\hline
\end{tabular}

The number of observations is 535. The Table shows the estimated coefficients and the standard errors (in parentheses). $* * *, * *$, and $*$ denote significance at the $1 \%, 5 \%$, and $10 \%$ levels, respectively. All regressions include time-dummies to control for year-specific effects. The multivariate probit (assuming normality of the error terms) provides with $\rho$, a correlation parameter that informs about the covariation of the error terms of the two decisions. If $\rho=0$, the probability of one decision is independent of the probability of the other decision.. 


\begin{tabular}{|c|c|c|c|c|}
\hline & $\begin{array}{c}(1) \\
\text { IntRD }\end{array}$ & $\begin{array}{c}(2) \\
\text { ExtRD } \\
\end{array}$ & $\begin{array}{c}(3) \\
\text { Machinery } \\
\end{array}$ & $\begin{array}{c}(4) \\
\text { Technical }\end{array}$ \\
\hline Lag of dependent & $\begin{array}{c}2.255^{* * *} * \\
(0.213)\end{array}$ & $\begin{array}{c}1.930 \text { *** } \\
(0.173)\end{array}$ & $\begin{array}{c}0.810^{* * * *} \\
(0.153)\end{array}$ & $\begin{array}{c}0.955^{* * * *} \\
(0.275)\end{array}$ \\
\hline Size (in logs) & $\begin{array}{c}0.331 * * * \\
(0.0671)\end{array}$ & $\begin{array}{c}0.271 * * * \\
(0.0615)\end{array}$ & $\begin{array}{c}-0.00251 \\
(0.0480)\end{array}$ & $\begin{array}{c}0.101 \\
(0.0990)\end{array}$ \\
\hline Age (in logs) & $\begin{array}{c}-0.0580 \\
(0.0941)\end{array}$ & $\begin{array}{c}0.0429 \\
(0.0860)\end{array}$ & $\begin{array}{c}0.0180 \\
(0.0720)\end{array}$ & $\begin{array}{c}0.104 \\
(0.113)\end{array}$ \\
\hline Public funds (t-1) & $\begin{array}{c}0.325 \\
(0.219)\end{array}$ & $\begin{array}{l}0.0266 \\
(0.192)\end{array}$ & $\begin{array}{c}0.0113 \\
(0.161)\end{array}$ & $\begin{array}{l}-0.164 \\
(0.256)\end{array}$ \\
\hline Foreign capital & $\begin{array}{l}0.353^{*} \\
(0.214)\end{array}$ & $\begin{array}{c}0.402 * * \\
(0.186)\end{array}$ & $\begin{array}{c}0.178 \\
(0.161)\end{array}$ & $\begin{array}{c}0.235 \\
(0.296)\end{array}$ \\
\hline Group & $\begin{array}{l}-0.0458 \\
(0.229)\end{array}$ & $\begin{array}{l}-0.0881 \\
(0.219)\end{array}$ & $\begin{array}{l}0.350^{*} \\
(0.203)\end{array}$ & $\begin{array}{c}4.188 \\
(134.3)\end{array}$ \\
\hline Product innovation & $\begin{array}{c}0.274 \\
(0.212)\end{array}$ & $\begin{array}{l}-0.0747 \\
(0.180)\end{array}$ & $\begin{array}{c}0.210 \\
(0.159)\end{array}$ & $\begin{array}{l}0.0753 \\
(0.259)\end{array}$ \\
\hline Process innovation & $\begin{array}{l}-0.157 \\
(0.222)\end{array}$ & $\begin{array}{l}0.0745 \\
(0.186)\end{array}$ & $\begin{array}{c}0.503 * * * \\
(0.172)\end{array}$ & $\begin{array}{l}-0.0736 \\
(0.290)\end{array}$ \\
\hline Environmental impact & $\begin{array}{l}0.389^{*} \\
(0.229)\end{array}$ & $\begin{array}{c}0.708 * * * \\
(0.206)\end{array}$ & $\begin{array}{r}-0.0449 \\
(0.191)\end{array}$ & $\begin{array}{l}0.494^{*} \\
(0.284)\end{array}$ \\
\hline Regulations & $\begin{array}{c}0.621 * * \\
(0.246)\end{array}$ & $\begin{array}{c}0.369 * \\
(0.209)\end{array}$ & $\begin{array}{c}-0.0780 \\
(0.190)\end{array}$ & $\begin{array}{l}-0.450 \\
(0.334)\end{array}$ \\
\hline Cost barrier & $\begin{array}{l}-0.194 \\
(0.350)\end{array}$ & $\begin{array}{l}0.0164 \\
(0.291)\end{array}$ & $\begin{array}{l}-0.239 \\
(0.263)\end{array}$ & $\begin{array}{l}-0.110 \\
(0.572)\end{array}$ \\
\hline Constant & $\begin{array}{c}-2.739 * * * \\
(0.557)\end{array}$ & $\begin{array}{c}-2.582 * * * * \\
(0.519)\end{array}$ & $\begin{array}{l}-0.370 \\
(0.412)\end{array}$ & $\begin{array}{l}-5.918 \\
(134.4)\end{array}$ \\
\hline $\operatorname{athrho}_{(I n t R D-E x t R D)}$ & \multicolumn{4}{|c|}{$\begin{array}{c}0.470 * * * \\
(0.133)\end{array}$} \\
\hline $\operatorname{athrho}_{(\text {IntRD-Machinery) }}$ & \multicolumn{4}{|c|}{-0.120} \\
\hline $\operatorname{athrho}_{(\text {IntRD-Technical })}$ & \multicolumn{4}{|c|}{0.135} \\
\hline $\operatorname{athrho}_{(E x t R D-M a c h i n e r y)}$ & \multicolumn{4}{|c|}{$\begin{array}{c}0.121 \\
(0.0925)\end{array}$} \\
\hline $\operatorname{athrho}_{(E x t R D-T e c h n i c a l)}$ & \multicolumn{4}{|c|}{$0.606 * * *$} \\
\hline $\operatorname{athrho}_{(\text {Machinery-Technical })}$ & \multicolumn{4}{|c|}{$\begin{array}{c}0.318 * * \\
(0.150)\end{array}$} \\
\hline
\end{tabular}

The number of observations is 398. The Table shows the estimated coefficients and the standard errors (in parentheses). $* * *, * *$, and $*$ denote significance at the $1 \%, 5 \%$, and $10 \%$ levels, respectively. All regressions include time-dummies to control for year-specific effects. The multivariate probit (assuming normality of the error terms) provides with $\rho$, a correlation parameter that informs about the covariation of the error terms of the two decisions. If $\rho=0$, the probability of one decision is independent of the probability of the other decision. 